\title{
Clinical characteristics of lung cancer patients with COVID-19: Retrospective case series
}

\author{
Yusuf KAHYA ${ }^{1}($ ID) \\ Güle ÇINAR ${ }^{2}$ (ID) \\ Buse Mine KONUK \\ BALCI $^{1}($ ID) \\ Cabir YÜKSEL ${ }^{\mathbf{1}}$ (ID) \\ Kemal Osman \\ MEMIKOĞLU ${ }^{2}(I D)$
}

\author{
${ }^{1}$ Department of Thoracic Surgery, Ankara University Faculty of Medicine, \\ Ankara, Turkey \\ ${ }^{1}$ Ankara Üniversitesi Tıp Fakültesi, Göğüs Cerrahisi Anabilim Dalı, \\ Ankara, Türkiye \\ ${ }^{2}$ Department of Infectious Diseases and Clinical Microbiology, Ankara \\ University Faculty of Medicine, Ankara, Turkey \\ ${ }^{2}$ Ankara Üniversitesi Tıp Fakültesi, Enfeksiyon Hastalıkları ve Klinik \\ Mikrobiyoloji Anabilim Dalı, Ankara Türkiye
}

Cite this article as: Kahya Y, Çınar G, Konuk Balcı BM, Yüksel C, Memikoğlu KO. Clinical characteristics of lung cancer patients with COVID-19: Retrospective case series. Tuberk Toraks 2021;69(4):499-509.

Yazışma Adresi (Address for Correspondence)

\section{Dr. Yusuf KAHYA}

Department of Thoracic Surgery,

Ankara University Faculty of Medicine,

ANKARA - TURKEY

e-mail: dr.yusufkahya@hotmail.com

CCopyright 2021 by Tuberculosis and Thorax.

Available on-line at www.tuberktoraks.org.com

\begin{abstract}
Clinical characteristics of lung cancer patients with COVID-19: Retrospective case series

Introduction: One of the patient groups adversely affected during the COVID19 pandemic is those suffering with cancer. The aim of this study was to evaluate the clinical characteristics and outcomes of lung cancer (LC) patients with COVID-19.

Materials and Methods: Three thousand seven-hundred and fifty hospitalized patients with a presumptive diagnosis of COVID-19 in a tertiary referral hospital between March 2020-February 2021 were retrospectively evaluated. Among them, 36 hospitalized COVID-19 patients with a history of primary LC were included in the study. Univariate and multivariate analyses were carried out to assess the risk factors associated with severe disease.

Results: Of the 36 patients included in the study, 28 (77\%) were males and $8(23 \%)$ were females. Median age was 67 years (min-max: 53-81 years). Six patients $(17 \%)$ had a diagnosis of small cell LC, whereas 30 patients $(83 \%)$ had a diagnosis of non-small cell LC. The most common symptoms were fever ( $n=28,77 \%)$, coughing and myalgia $(n=21,58 \%)$ and dyspnea $(n=18$, $50 \%)$. The most common radiological finding was ground glass opacity (GGO) ( $n=30)$, of which 13 was bilateral and 17 was unilateral in distribution. Nearly $30 \%(n=11)$ of LC patients with COVID-19 developed severe disease, $5 \%(n=2)$ of the 36 patients were admitted to intensive care unit and all of these patients eventually expired. LC patients with COVID-19 and patchy consolidation on computed tomography of thorax (Th CT) on admission had a higher risk of developing severe disease in univariate (HR 2.41, 95\% Cl: 1.4$4.4, p=0.04$ ) and multivariate Cox regression analysis (HR $0.48,95 \% \mathrm{Cl}$ : $0.24-0.97, p=0.03$ )
\end{abstract}


Conclusion: Clinical characteristics, laboratory and radiographic findings were similar in LC patients with COVID-19 when compared with the general population, $L C$ patients have a higher mortality rate than the general population, with a $5 \%$ mortality rate in our series. Our findings suggest that LC may be a risk factor associated with the prognosis of COVID-19 patients.

Key words: COVID-19; lung cancer; treatment

\section{ÖZ}

\section{COVID-19'lu akciğer kanseri hastalarının klinik karakteristik özellikleri: Geriye dönük vaka serisi}

Giriş: Koronavirüs hastalığı 2019 (COVID-19) pandemisinden olumsuz etkilenen hasta gruplarından biri de kanser hastalarıdır. Bu çalışmanın amacı COVID-19'lu akciğer kanseri (AK) hastalarında COVID-19'un klinik seyrinin ve sonuçlarının değerlendirmesidir.

Materyal ve Metod: Mart 2020-Şubat 2021 tarihleri arasında COVID-19 ön tanısı ile üçüncü basamak hastaneye yatırılarak tedavisi düzenlenen 3750 hasta geriye dönük araştırıldı. Bu hastalar arasından primer AK öyküsü olan 36 hasta çalışmaya dahil edildi. Şiddetli hastalık seyri ile ilişkili risk faktörlerini değerlendirmek için tek değişkenli ve çok değişkenli analizler yapıldı.

Bulgular: Çalışmaya dahil edilen 36 hastanın 28'i (\%77) erkek, 8'i (\%23) kadındı. Medyan yaş 67 yıldı (min-max: 53-81 yıl). Altı (\% 17) hastada küçük hücreli AK, 30 (\%83) hastada küçük hücreli dışı AK tanısı vardı. En sık görülen semptomlar ateş ( $n=28, \% 77)$, öksürük ve miyalji ( $n=21, \% 58)$ ve dispne ( $n=18, \% 50)$ idi. En sık radyolojik bulgu buzlu cam opasitesi (BCO) ( $n=30)$ olup, 13 hastada bilateral ve 17 hastada unilateral yerleşimliydi. Hastaların \%30'unda $(n=11)$ hastalığın seyri şiddetliydi, yoğun bakım desteği verilen $2(\% 5)$ hastada exitus gelişti. Başvuru sırasındaki toraks bilgisayarlı tomografide yamalı konsolidasyon varlığı tek değişkenli ( HR 2,41, \%95 Cl: 1,4-4,4, p=0,04) ve çok değişkenli Cox regresyon analizinde (HR 0,48, \%95 Cl: 0,24-0,97, p=0,03) şiddetli hastalık gelişme riski açııından anlamlı bulundu.

Sonuç: Bu çalışmada COVID-19'lu AK hastalarının klinik özellikleri, laboratuvar ve radyografik bulguları genel popülasyona göre benzer olmakla birlikte, ölüm oranı \%5 bulunmuş ve genel popülasyondan yüksek olduğu gösterilmiştir. Bulgularımız, COVID-19 hastalarında AK varlığının prognostik gösterge olabileceğini desteklemektedir.

Anahtar kelimeler: COVID-19; akciğer kanseri; tedavi

\section{INTRODUCTION}

Coronavirus disease 2019 (COVID-19) is caused by a novel coronavirus, namely severe acute respiratory syndrome coronavirus 2 (SARS-CoV-2). The first case of novel coronavirus was reported in Wuhan, China, in late December 2019. On 11 March 2020, COVID19 was declared a pandemic by the World Health Organization (WHO) (1).

One of the patient groups adversely affected during the COVID-19 pandemic is patients suffering with cancer. These patients are more susceptible to infection than those without cancer because of their systemic immunosuppressive state caused by the malignancy and anticancer treatments, such as chemotherapy $(\mathrm{CT})$, radiotherapy $(\mathrm{RT})$, chemoradiotherapy (CRT) or surgery and have a higher intensive care hospitalization and mortality rate. At the same time, the impact of COVID-19 on lung cancer (LC) patients has been reported in several studies with increased mortality noted when compared with other cancer types (2-9). There is limited information about the clinical characteristics and outcomes of LC patients with COVID-19. This study discusses the clinical characteristics and outcomes of LC patients with COVID-19.

\section{MATERIALS and METHODS}

Three thousand seven-hundred and fifty hospitalized patients with a presumptive diagnosis of COVID-19 in a tertiary referral hospital between March 2020-February 2021 were retrospectively evaluated. Among them, 36 hospitalized COVID-19 patients with a history of primary LC were included in the study. Patients with metastatic lung disease were not included.

COVID-19 was diagnosed with positive reverse transcriptase- polymerase chain reaction (RT-PCR) results obtained from nasopharyngeal and oropharyngeal swabs as well as clinical, laboratory and imaging findings (according to the WHO criteria). Patients who presented clinical symptoms and laboratory and/or imaging findings suggestive of COVID-19 were included despite negative RT-PCR results. All data regarding the patients such as demographical information, clinical presentation and course, pathological results, laboratory test results, imaging findings and reports were extracted from the local hospital network. For tumour staging, $8^{\text {th }}$ Edition of TNM Classification for Lung Cancer proposed by the International Association for the Study of Lung Cancer 
(IASLC) was used. Community acquired transmission is accepted as the route of transmission for immunocompetent patients who acquired the infection during routine daily life, whereas nosocomial route was deemed as the route of transmission for the simultaneous infection of a patient group in the same hospital ward. The date of pathological report of the surgical or tissue specimen was accepted as the exact date of diagnosis for LC. The date when Infectious Diseases \& Clinical Microbiology Department concluded a definite diagnosis was accepted as the exact date of the COVID-19 diagnosis. Blood samples were drawn from patients for an evaluation of the total blood count, biochemical tests, coagulation parameters, inflammatory markers and cardiac markers. Radiological evaluation was performed with low dose nonenhanced computed tomography of thorax (Th $\mathrm{CT}$ ) scans. In accordance with previous reports on COVID-19 imaging, the following patterns were sought: ground-glass opacity (GGO), crazy paving (GGO associated with interlobular septal thickening), focal consolidation and linear consolidation. The predominant pattern was determined for each radiological examination. This study was approved by the local institutional review board (Approval date: March 29, 2021, No: i3-229-21).

\section{Disease Severity}

According to the "Report of the WHO-China Joint Mission on Coronavirus Disease 2019" the majority of people infected with SARS-CoV-2 are only mildly affected and recover. Approximately $80 \%$ of laboratory confirmed patients are mild to moderate cases, which includes non-pneumonia and pneumonia cases, $13.8 \%$ have severe cases of COVID-19 (dyspnea, respiratory frequency $\geq 30 /$ minute, blood oxygen saturation $\leq 93 \%, \mathrm{PaO}_{2} / \mathrm{FiO}_{2}$ ratio $50 \%$ of the lung field within 24-48 hours) and $6.1 \%$ are critical (respiratory failure, septic shock, and/or multiple organ dysfunction/failure) (10). Acute respiratory distress syndrome (ARDS) was defined according to the interim guidance of WHO for COVID-19 (11).

\section{Statistical Analysis}

For descriptive analysis, continuous variables were presented as median while categorical variables as a number (\%). Mann-Whitney $U$ test was used to analyse continuous variables. Chi-square method was used to compare differences between two groups. To explore potential factors of LC patients with COVID19 developing severe clinical disease, the hazard ratio $(H R)$ and the corresponding 95\% confidence intervals $(\mathrm{Cl})$ from the Cox proportional hazards model were calculated. All statistical analyses were carried out using SPSS Statistics version 26.0 (IBM, New York, NY). A P-value of $<0.05$ was considered statistically significant.

\section{RESULTS}

Of the 36 patients analysed, 28 (77\%) were males and $8(23 \%)$ were females, with a median age of 67 years (min-max: $53-81$ years). Thirty-two (88\%) of the patients had a history of smoking. Six patients $(17 \%)$ had a diagnosis of small cell LC (SCLC), whereas 30 $(83 \%)$ patients had a diagnosis of non-small cell LC (NSCLC). The histopathological subtypes of NSCLC were as follows: squamous cell cancer (SCC) $(n=17$, $56 \%)$, adenocarcinoma $(n=12,41 \%)$, atypical carcinoid tumour $(n=1,3 \%)$. Six $(17 \%)$ patients did not have any comorbidity; however, 12 (33\%) patients had one and 18 (50\%) patients had multiple comorbidities. The most common comorbidities were essential hypertension $(H T) \quad(n=24,80 \%)$, type 2 diabetes mellitus (DM) $(n=16,53 \%)$ and chronic obstructive pulmonary disease (COPD) $(n=10,33 \%)$. Three patients had a history of second malignancy other than LC: one patient underwent CRT for classical Hodgkin's lymphoma in 2012 with subsequent cure, one patient had an ongoing therapy of $500 \mathrm{mg}$ Bosutinib for chronic myeloid leukaemia, and one patient had a recent diagnosis of urothelial carcinoma. Regarding the method of transmission, 12 (33\%) patients had nosocomial, whereas 24 (67\%) patients had community acquired infection.

Twenty (55\%) patients underwent surgery and 16 $(45 \%)$ patients had CT \pm RT history for treatment of LC before their COVID-19 diagnosis. All patients treated in surgery had NSCLC. The surgical resection details were as follows: lobectomy $(n=17,85 \%)$, sublobar resection $(n=2,10 \%)$, pneumonectomy $(n=$ $1,5 \%$ ). We achieved R0 (free microscopic margins) resection in 19 patients and $\mathrm{R} 1$ resection (cancer cells present microscopically at the primer tumour site) in one patient. One patient with a right upper lobectomy had a history of previous left lower lobectomy due to bronchiectasia 20 years ago. One patient with a superior sulcus tumour underwent neoadjuvant CRT, surgical treatment and adjuvant $\mathrm{CT}$, respectively. Five patients received adjuvant CT treatment for pathological hilar lymph nodes. Of the 16 patients who were not treated surgically, ten had 
definitive CT and six had definitive CRT treatment. Twelve patients received anticancer treatment in the last month before a confirmed diagnosis of COVID19. Four of them were treated with surgery while the other eight underwent $\mathrm{CT} \pm \mathrm{RT}$. The relevant demographical and clinical information of the patients are summarized in Table 1.

Thirty of the patients showed multiple symptoms of COVID-19 while six of the patients showed only one symptom. The most common symptoms were fever $(n=28,77 \%)$, coughing and myalgia $(n=21,58 \%)$ and dyspnea $(n=18,50 \%)$. Mean time from symptoms to hospitalization was seven days (min-max: 1-10 days). The most common laboratory findings were; lymphopenia $(n=30,83 \%)$, high levels of $C$ reactive protein (CRP) $(n=27,75 \%), D$-Dimer $(n=$ $27,75 \%)$ and ferritin $(n=27,75 \%)$. Twelve $(30 \%)$ patients had a positive RT-PCR result. Thirty-three patients had findings suggestive of COVID-19 pneumonia on Th CT scans. The common radiological finding was ground glass opacity (GGO) $(n=30)$, of whose distribution was bilateral in 13 patients and unilateral in 17 patients. Fourteen patients had areas of patchy consolidation. Two patients had crazy paving pattern, two patients had focal consolidation, and two patients had linear consolidation (Figure 1, 2).

During hospitalization, all patients received the standard medical treatment of antiviral drugs and heparin. When required, antibiotics (for coinfections etc.) and oxygen as well as steroids (for severe disease) were administered. The medications used during the treatment were as follows; hydroxychloroquine (HCQ) $(n=10,200 \mathrm{mg}$ orally twice a day for five days), favipiravir ( $\mathrm{n}=26,2 \times 1600 \mathrm{mg}$ peroral loading dose, 2x600 mg peroral for four days maintenance dose), azithromycin (AZM) $(n=8,500$ mg orally once a day for five days), levofloxacin (LVX) $(n=4,750 \mathrm{mg}$ orally once a day), piperacillin/tazobactam (TZP) (n= 4, 4,5 gr intravenously four times a day), systemic corticosteroids $(n=11$, dexametasone $1 \times 6 \mathrm{mg}$ intravenously or metylprenisolone $2 \times 40 \mathrm{mg}$ intravenously). A prophylactic dose of enoxaparin was added to the treatment to prevent the thrombotic complications of COVID-19. Antibiotics were administered in addition to the antiviral treatment in 16 patients (HCQ and AZM in 8 patients, favipiravir and TZP 4 patients, HCQ in two patients, favipiravir and LVX in 2 patients) (Table 2). Antibiotherapy was initiated in 11 patients empirically, for an accompanying urinary tract infection in two patients and bacterial pneumo- nia in one patient. None of the patients experienced adverse effects of antiviral drugs.

In 11 patients, severe disease was noted. These patients received oxygen therapy either via nasal cannula, mask or mask with reservoir in order to keep $\mathrm{SpO}_{2}$ levels over $90 \%$ and systemic corticosteroid $(30 \%$ ) (favipiravir and corticosteroid for 8 patients, HCQ and corticosteroid for three patients). Clinical information about the patients with severe and non-severe disease are provided in Table 3. Over the course of the disease, 34 patients exhibited progressive improvement upon treatment and were eventually discharged. Median hospital stay period for these patients was 8 days (min-max: 2-19 days). Two patients were transferred to the intensive care unit (ICU) because of clinical deterioration and a need for mechanical ventilation. Both patients expired on days seven and 14 after the transfer to the ICU due to the development of COVID-19 related ARDS (Figure 3). The mortality rate in our series was $5 \%$.

LC patients with COVID-19 and patchy consolidation on Th CT on admission had a higher risk of developing severe disease in univariate (HR 2.41, 95\%Cl: 1.4-4.4, $\mathrm{p}=0.04$ ) and multivariate Cox regression analysis (HR $0.48,95 \% \mathrm{Cl}: 0.24-0.97, \mathrm{p}=$ 0.03) (Table 4).

\section{DISCUSSION}

COVID-19 is an infectious disease with variable clinical course and worse reported outcomes in patients with certain pre-existing comorbid conditions.

Patients with cancer are particularly susceptible to respiratory pathogens and severe pneumonia, because they are at an immunosuppressive state due to malignancy and antitumor therapy (6).

Observations from other studies confirm active malignancy as an independent risk factor for increased severity of illness and mortality from COVID-19. Similarly, the impact of COVID-19 on LC patients has been reported in several studies with a noted increase in mortality when compared with other cancer types (12-14).

While 368 LC patients were followed under pandemic conditions in last one-year period in a tertiary referral hospital, 36 of them were diagnosed with COVID-19. Of the 36 patients, $61 \%$ had active disease or were on active treatment. 
Table 1. Summary of clinical characteristics of LC patients with COVID-19

\section{Characteristics}

Age, median (range) (years) 67 (53-81)

Sex

Male

Female

Tumor type

SCLC

NSCLC

-Adenocarcinoma

-SCC

-Atypical carcinoid

Tumor stage

Stage I

Stage II

Stage III

Stage IV

History of prior cancer treatment

Non Surgery

$-\mathrm{CT}$

-CRT

Surgery

-Lobectomy

-Sublobar resection

-Pneumonectomy

Time from last anticancer treatment to diagnosis of COVID-19

$$
\begin{aligned}
& \leq 1 \text { mont } \\
& \text {-Surgery } \\
& -\mathrm{CT} \pm \mathrm{R} \\
& >1 \text { month } \\
& \text {-Surgery } \\
& -\mathrm{CT} \pm \mathrm{RT}
\end{aligned}
$$

Source of infection

Community aqcuried

Nosocomial transmission

Comorbidities

DM

HT

CAD

COPD1

Prior malignancy

Symptoms and signs at on admission

Fever

Cough

\begin{tabular}{|c|c|}
\hline 28 & 77 \\
\hline 8 & 23 \\
\hline 6 & 17 \\
\hline 30 & 83 \\
\hline 12 & 41 \\
\hline 17 & 56 \\
\hline 1 & 3 \\
\hline 15 & 41 \\
\hline 5 & 14 \\
\hline 9 & 26 \\
\hline 7 & 19 \\
\hline 10 & 62 \\
\hline 6 & 38 \\
\hline 17 & 85 \\
\hline 2 & 10 \\
\hline 1 & 5 \\
\hline 4 & 12 \\
\hline 8 & 22 \\
\hline 16 & 44 \\
\hline 8 & 22 \\
\hline 24 & 67 \\
\hline 12 & 33 \\
\hline 16 & 53 \\
\hline 24 & 80 \\
\hline 5 & 16 \\
\hline 10 & 33 \\
\hline 3 & 10 \\
\hline 28 & 77 \\
\hline 21 & 58 \\
\hline 11 & 30 \\
\hline 21 & 58 \\
\hline 6 & 16 \\
\hline
\end{tabular}

Dyspnea

Myalgia

Chest pain

LC: Lung cancer, NSCLC: Non small cell lung cancer, SCLC: Small cell lung cancer, SCC: Squamous cell lung cancer, CT: Chemotherapy, RT: Radiotherapy, CRT: Chemoradiotherapy, COPD: Chronic obstructive pulmonary disease, CAD: Coronary artery disease, HT: Essential hypertension, DM: Type 2 diabetes mellitus. 


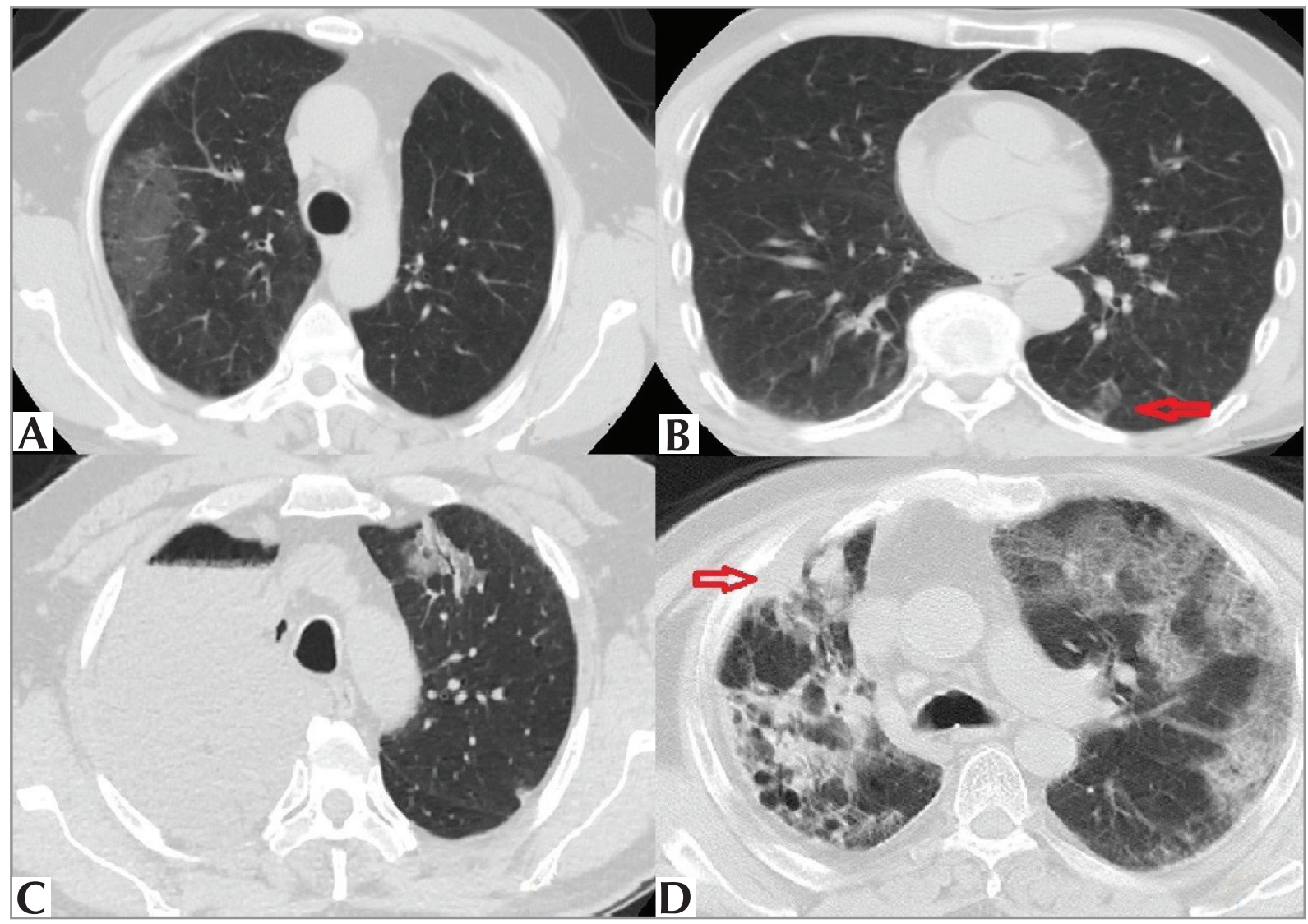

Figure 1. GGO is visualized at the right lung upper lobe in a patient with a history of left lower lobectomy on Th CT (A), Linear consolidation (arrow) is seen at left lung lower lobe in a patient operated for Pancoast tumor (B), Focal consolidation is seen at left lung upper lobe in a patient with a history of right pneumonectomy on Th CT (C), Both bilateral widespread crazy paving pattern and locally invasive LC located at the right lung upper lobe (arrow) can be seen on Th CT (D).

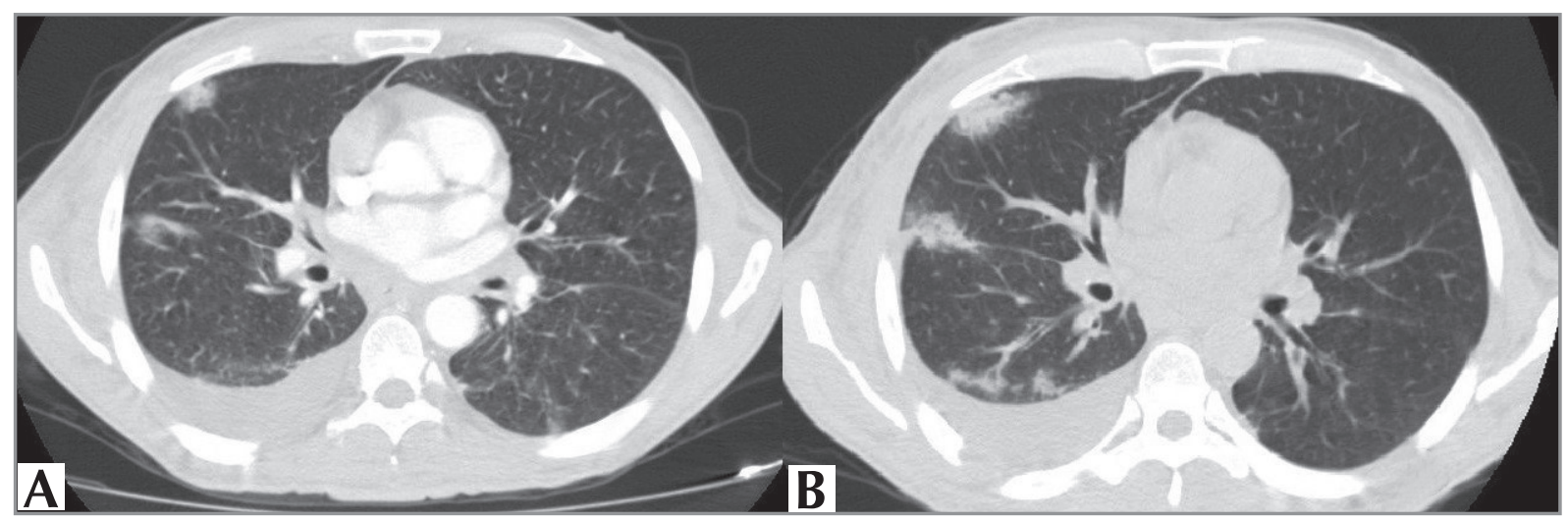

Figure 2. Areas of patchy consolidation are seen at the right lung upper lobe and around the major fissure (A), Control Th CT scan obtained 9 days later reveals increased parenchymal findings (B).

In line with much of the literature, the disease course of COVID-19 is more severe in patients with LC (12).
As much as $30 \%$ of the LC patients with COVID-19 developed severe disease, $5 \%$ of all patients were admitted to intensive care unit and these patients 
Table 2. Treatment and clinical outcome of LC patients with COVID-19

\begin{tabular}{|c|c|c|}
\hline & $\mathbf{n}$ & $\%$ \\
\hline \multicolumn{3}{|l|}{ Treatment type } \\
\hline \multicolumn{3}{|l|}{ Medicine therapy } \\
\hline \multicolumn{3}{|l|}{-Antiviral treatment } \\
\hline HCQ & 10 & 27 \\
\hline Favipiravir & 26 & 72 \\
\hline -Antibiotic treatment & 16 & 44 \\
\hline -Systemic corticosteroids & 11 & 30 \\
\hline Oxygen therapy & 11 & 30 \\
\hline Severe events & 11 & 30 \\
\hline Mechanical ventilation & 2 & 5 \\
\hline Admission to intensive care unit & 2 & 5 \\
\hline \multicolumn{3}{|l|}{ Clinical symptoms evaluation } \\
\hline Improvement & 34 & 95 \\
\hline Worse (Death) & 2 & 5 \\
\hline
\end{tabular}

died. As of the end of February 2021, a total of 2,723,316 COVID-19 cases and a total of 28,706 deaths $(1.05 \%)$ have been officially recorded in Turkey (15).

It was noted that $33 \%$ of our patients had developed COVID-19 during hospitalisation and nosocomial transmission of SARS-CoV-2 was suspected.

In a retrospective case study with 138 patients, $41.3 \%$ of the patients have been reported to have acquired COVID-19 during hospitalisation, and of these, five patients were from the oncology department (16).

Similar to the general population with COVID-19, a variable clinical presentation is also noted in LC patients with COVID-19 (12). Our results showed the following clinical features of LC patients with COVID19: typical symptoms of fever, dry cough, and myalgia. Seventeen percent of the patients had one symptom whereas $83 \%$ of the patients had multiple symptoms. The time from initial symptom to hospitalisation was seven days (1-10 days). The most common laboratory findings were; lymphopenia (83\%), high levels of CRP (75\%), D-Dimer (75\%) and ferritin (75\%).

GGO and patchy consolidation were both common Th CT findings in LC patients with COVID-19, similar to the features in the general population. Patchy con- solidation can rapidly evolve into bilateral extensive consolidation, with a white lung appearance on Th $\mathrm{CT}$, leading to poor prognosis (17).

In this study, LC patients with COVID-19 and patchy consolidation on Th CT on admission had a higher risk of developing severe disease in univariate (HR 2.41, 95\%Cl: 1.4-4.4) and multivariate Cox regression analysis (HR 0.48, 95\%Cl: 0.24-0.97). Patchy consolidation usually appeared in the first to second weeks after symptom onset.

In our study, all 36 patients were prescribed an antiviral agent. Currently, however, there is no drug that has been proven to be effective against SARS-CoV-2. Consistent with a recent retrospective study out of New York City and a randomized controlled study in China, our investigation of $\mathrm{HCQ}$ did not find an improvement in COVID-19 severity outcomes among patients with LC. Systemic corticosteroids remain controversial in the treatment of viral pneumonia. Usage of steroids has been considered to slow virus clearance due to its immunosuppressive effect, which was often associated with an increased risk of opportunistic infections, especially in patients who required mechanical ventilation (14). As all of our severe patients received steroids treatment, we could not compare the effect of steroids treatment on LC patients with COVID-19. 
Table 3. Distribution of patients according to clinical outcomes

\begin{tabular}{|c|c|c|c|}
\hline & Severe event $(n=11)$ & Non severe event $(n=25)$ & $\mathbf{p}$ \\
\hline \multicolumn{4}{|l|}{ Patient characteristics } \\
\hline \multicolumn{4}{|l|}{ Gender } \\
\hline Male & 10 & 19 & 0.21 \\
\hline Female & 1 & 6 & \\
\hline \multicolumn{4}{|l|}{ Age (median) (years) } \\
\hline$\leq 67$ & 7 & 15 & 0.17 \\
\hline$>67$ & 4 & 10 & \\
\hline \multicolumn{4}{|c|}{ Time from symptoms to hospitalisation (mean) (days) } \\
\hline$\leq 7$ & 3 & 22 & 0.38 \\
\hline$>7$ & 8 & 3 & \\
\hline \multicolumn{4}{|l|}{ LC type } \\
\hline NSCLC & 10 & 20 & 0.06 \\
\hline SCLC & 2 & 4 & \\
\hline \multicolumn{4}{|l|}{ Stage } \\
\hline Stage I-II & 5 & 15 & 0.82 \\
\hline Stage III-IV & 6 & 10 & \\
\hline \multicolumn{4}{|c|}{ Anticancer treatment time (months) } \\
\hline$\leq 1$ & 9 & 13 & 0.12 \\
\hline$>1$ & 2 & 12 & \\
\hline \multicolumn{4}{|l|}{ Anticancer treatment type } \\
\hline Surgery & 5 & 15 & 0.07 \\
\hline Non surgery & 6 & 10 & \\
\hline \multicolumn{4}{|l|}{ Th CT findings } \\
\hline Patchy consolidation & 9 & 5 & 0.8 \\
\hline No patchy consolidation & 2 & 20 & \\
\hline \multicolumn{4}{|l|}{ Antiviral treatment } \\
\hline $\mathrm{HCQ}$ & 3 & 6 & 0.43 \\
\hline Favipiravir & 8 & 19 & \\
\hline
\end{tabular}

This study is limited due to its retrospective nature and small sample size. Larger sample sizes and cohorts are needed to confirm the generalizability of our results. Although we identified LC specific features that impacted severity; prior thoracic surgery, thoracic radiation, near-term systemic therapies, clinicopathologic features of LC and demographic characteristics such as age and gender, and the univariable and multivariable analyses showed no statistically significant associations, we still suggest that the stage of cancer, type of anticancer treatment, age and sex may affect the clinical course of LC patients with COVID-19.
Due to retrospective descriptive study design, we only reported rates of complications and fatality in LC patients with COVID-19. The comparisons between LC and noncancer patients with COVID-19 could reveal more useful information, as would comparisons of less severe cases not included in our study population. Future studies with larger sample sizes and prospective study designs are warranted to further explore the risk factors and severe disease in LC patients with COVID-19. 


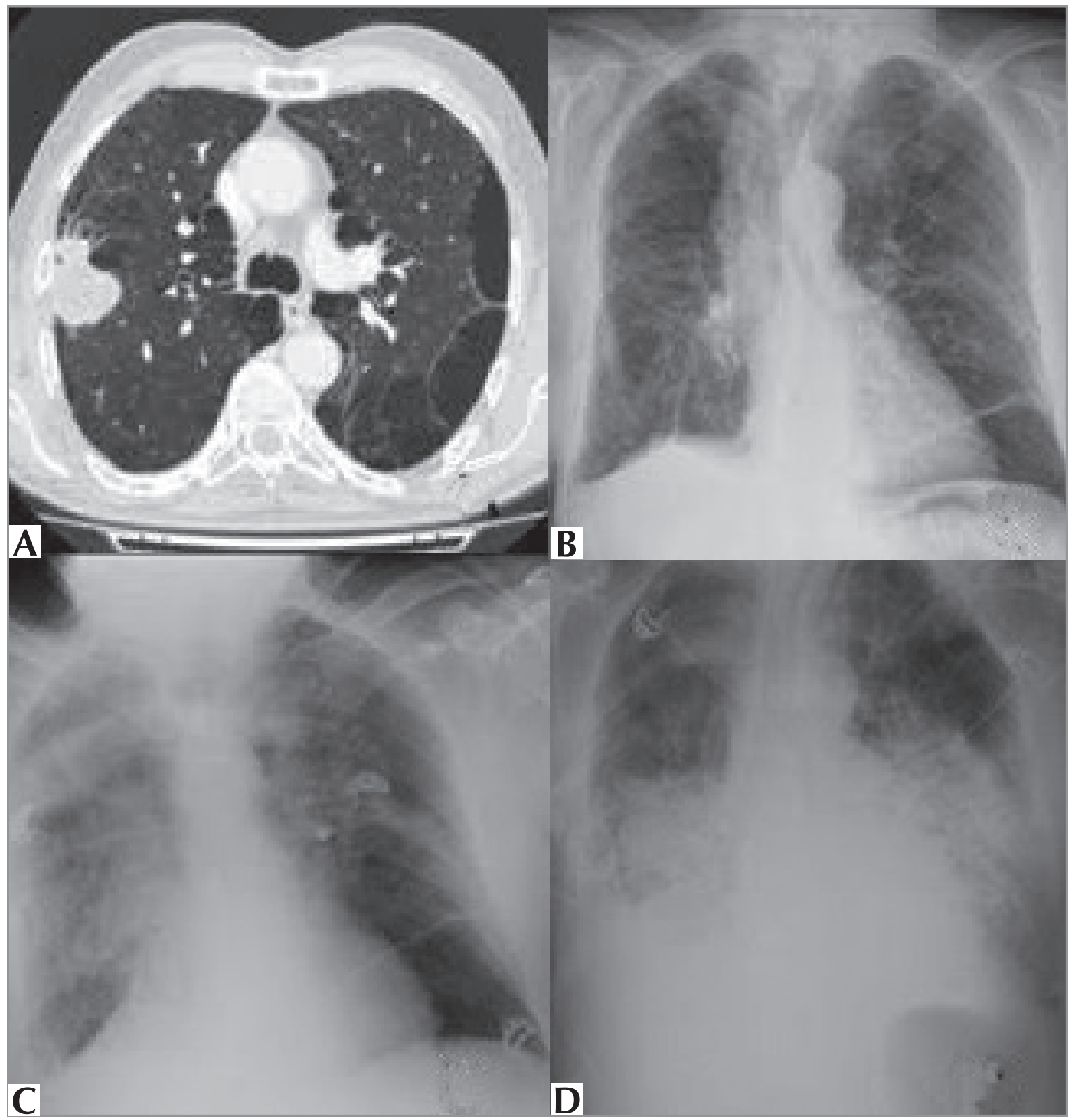

Figure 3. 64-year-old male patient had a fever of $38.5^{\circ} \mathrm{C}$ and positive RT-PCR result ten days after the surgery of a stage II SCC located at the right lung upper lobe. Preoperative Th CT demonstrates emphysema and a right lung mass (A). The patient was transferred to the intensive care unit due to clinical deterioration. Progression of the pulmonary involvement can be traced on chest $\mathrm{X}$-rays at postoperative ten days (B), 17 days (C) and 30 days (D). After a treatment period of two weeks with mechanical ventilation support, the patient expired 30 days after the procedure due to COVID-19 related ARDS.

In conclusion, clinical characteristics, laboratory and radiographic findings were similar in LC patients with COVID-19 compared to the general population, LC patients have a higher mortality rate than the general population, with 5\% (two deaths) mortality rate in our series. Our findings suggest that LC may be the risk factor associated with the prognosis of COVID19 patients. 
Table 4. The results of univariate and multivariate Cox regression models for developing severe events

\begin{tabular}{|c|c|c|c|c|}
\hline \multirow[b]{2}{*}{ Variables } & \multicolumn{2}{|c|}{ Univariate } & \multicolumn{2}{|c|}{ Multivariate } \\
\hline & $\mathbf{p}$ & HR $(95 \% \mathrm{CI})$ & $\mathbf{p}$ & HR $(95 \% \mathrm{Cl})$ \\
\hline Male vs female & 0.34 & $1.28(0.74-2.2)$ & 0.8 & $1.01(0.56-2.1)$ \\
\hline Age (median) (years) $\leq 67$ vs $>67$ & 0.56 & $0.68(0.45-2.11)$ & 0.65 & $0.81(0.35-1.13)$ \\
\hline $\begin{array}{l}\text { Time from symptoms to hospitalisation (mean) } \\
\text { (days) } \leq 7 \mathrm{vs}>7\end{array}$ & 0.07 & $0.34(0.53-2.73)$ & 0.88 & $0.44(0.74-2.83)$ \\
\hline SCLC vs NSCLC & 0.9 & $0.47(0.15-1.42)$ & 0.12 & $0.64(0.14-2.93)$ \\
\hline Stage I-II vs stage III-IV & 0.87 & $0.85(1.35-4.58)$ & 0.46 & $0.58(0.32-10.1)$ \\
\hline Anticancer treatment time (months) $\leq 1$ vs $>1$ & 0.56 & $2.52(0.32-3.03)$ & 0.72 & $1.64(0.99-2.77)$ \\
\hline Surgery vs non surgery & 0.49 & $3.02(0.29-3.13)$ & 0.61 & $2.82(0.99-3.47)$ \\
\hline Patchy consolidation vs no patchy consolidation & 0.04 & $2.41(1.4-4.4)$ & 0.03 & $0.48(0.24-0.97)$ \\
\hline HCQ vs favipiravir & 0.59 & $0.6(0.18-1.26)$ & 0.57 & $0.49(0.14-2.85)$ \\
\hline
\end{tabular}

Ethical Committee Approval: This study approval was obtained from Ankara University Faculty of Medicine Clinical Researches Ethical Committee (Decision No: i3-229-21, Date: 29.03.2021).

\section{CONFLICT of INTEREST}

The authors declare that they have no conflict of interest.

\section{AUTHORSHIP CONTRIBUTIONS}

Concept/Design: YK, BMKB, GÇ

Analysis/Interpretation: BMKB, GÇ

Data acqusition: YK, BMKB

Writing: YK, GÇ

Clinical Revision: $\mathrm{CY}, \mathrm{KOM}$

Final Approval: CY, KOM

\section{REFERENCES}

1. Peravali M, Joshi I, Ahn J, Kim C. A Systematic Review and Meta-Analysis of Clinical Characteristics and Outcomes in Patients With Lung Cancer with Coronavirus Disease 2019. JTO Clin Res Rep 2021 Mar; 2(3): 100141.

2. Mehta V, Goel S, Kabarriti R, Cole D, Goldfinger M, AcunaVillaorduna A, et al. Case Fatality Rate of Cancer Patients with COVID-19 in a New York Hospital System. Cancer Discov 2020 Jul; 10(7): 935-41.

3. Yang $K$, Sheng $Y$, Huang $C$, Jin $Y$, Xiong $N$, Jiang $K$, et al. Clinical characteristics, outcomes, and risk factors for mortality in patients with cancer and COVID-19 in Hubei, China: a multicentre, retrospective, cohort study. Lancet Oncol $2020 \mathrm{Jul} ; 21$ (7): 904-913.
4. Peng S, Huang L, Zhao B, Zhou S, Braithwaite I, Zhang N, et al. Clinical course of coronavirus disease 2019 in 11 patients after thoracic surgery and challenges in diagnosis. J Thorac Cardiovasc Surg 2020 Aug; 160(2): 585-592.e2.

5. Rogado J, Obispo B, Pangua C, Serrano-Montero G, Martín Marino A, Pérez-Pérez $M$, et al. Covid-19 transmission, outcome and associated risk factors in cancer patients at the first month of the pandemic in a Spanish hospital in Madrid. Clin Transl Oncol 2020 Dec; 22(12): 2364-8.

6. Yu J, Ouyang W, Chua MLK, Xie C. SARS-CoV-2 Transmission in Patients With Cancer at a Tertiary Care Hospital in Wuhan, China. JAMA Oncol 2020 Jul 1; 6(7): 1108-10.

7. Dai M, Liu D, Liu M, Zhou F, Li G, Chen Z, et al. Patients with Cancer Appear More Vulnerable to SARS-CoV-2: A Multicenter Study during the COVID-19 Outbreak. Cancer Discov 2020 Jun; 10(6): 783-91.

8. Yarza $R$, Bover M, Paredes D, López-López F, Jara-Casas $D$, Castelo-Loureiro A, et al. SARS-CoV-2 infection in cancer patients undergoing active treatment: analysis of clinical features and predictive factors for severe respiratory failure and death. Eur J Cancer 2020 Aug; 135: 242-50.

9. Assaad S, Avrillon V, Fournier ML, Mastroianni B, Russias B, Swalduz $A$, et al. High mortality rate in cancer patients with symptoms of COVID-19 with or without detectable SARSCOV-2 on RT-PCR. Eur J Cancer 2020 Aug; 135:251-9.

10. World Health Organization (WHO). Report of the WHOChina Joint Mission on Coronavirus Disease 2019 (COVID19). Available from: https://www.who.int/publications/i/ item/report-of-the-who-china-joint-mission-on-coronavirusdisease-2019-(covid-19). Accessed date: 28 February 2020.

11. World Health Organization (WHO). Clinical management of severe acute respiratory infection when novel coronavirus (nCoV) infection is suspected. Available from: https:// https://www.who.int/publications/i/item/10665-332299. Accessed date: 4 April 2020. 
12. Rogado J, Pangua C, Serrano-Montero G, Obispo B, Marino AM, Pérez-Pérez M, et al. Covid-19 and lung cancer: A greater fatality rate? Lung Cancer 2020 Aug; 146: 19-22.

13. Liang W, Guan W, Chen R, Wang W, Li J, Xu K, et al. Cancer patients in SARS-CoV-2 infection: a nationwide analysis in China. Lancet Oncol. 2020 Mar; 21(3): 335-7.

14. Zhang L, Zhu F, Xie L, Wang C, Wang J, Chen R, et al. Clinical characteristics of COVID-19-infected cancer patients: a retrospective case study in three hospitals within Wuhan, China. Ann Oncol 2020 Jul; 31(7): 894-901.
15. T.C. Sağlık Bakanlı̆̆ı COVID-19 Bilgilendirme Platformu. Available from: https://covid19.saglik.gov.tr/TR-66935/ genel-koronavirus-tablosu.html. Accessed date: 2.March 2021

16. Wang $D, H u B, H u$ C, Zhu F, Liu X, Zhang J, et al. Clinical Characteristics of 138 Hospitalized Patients With 2019 Novel Coronavirus-Infected Pneumonia in Wuhan, China. JAMA 2020 Mar 17; 323(11): 1061-1069.

17. Guan WJ, Ni ZY, Hu Y, Liang WH, Ou CQ, He JX, et al. Clinical Characteristics of Coronavirus Disease 2019 in China. N Engl J Med 2020 Apr 30; 382(18): 1708-20. 